\title{
Predictors of Electoral Participation among Spanish and Latin American Undergraduates
}

\author{
José Juan Vázquez ${ }^{1}$, Sonia Panadero², Ana B. García-Varela ${ }^{1}$ \\ ${ }^{1}$ Universidad de Alcalá, Alcalá de Henares, Spain \\ ${ }^{2}$ Universidad Complutense de Madrid, Madrid, Spain \\ Email: jj.vazquez@uah.es, spanadero@psi.ucm.es, abelen.garcía@uah.es
}

Received September 14 $4^{\text {th }}, 2012$; revised October $18^{\text {th }}, 2012$; accepted November $4^{\text {th }}, 2012$

\begin{abstract}
This paper presents the results of a study of 709 undergraduates in Nicaragua, El Salvador, Chile, and Spain, countries with different developmental levels that held the first free elections following their respective dictatorships within a thirteen year span. The paper analyzes the electoral participation of undergraduates in relation to different factors. Results show a high electoral participation among Salvadoran, Nicaraguan, and Spanish undergraduates, while low turnout is observed among Chileans. The best predictors of electoral participation of undergraduates are related to their nationality, economic status, interest in politics, gender or living away from home.
\end{abstract}

Keywords: Electoral Participation; Predictors; Latin-America; Spain

\section{Introduction}

Voter turnout has been a major area of interest in most states, especially when they describe themselves as democratic. Special attention has been paid to aspects related with new voter turnout, in particular when there is a decline in the interest and motivation of young people into political action (Ellis, 2004) that could result, among other things, from such factors as poor self-perception as agents of social change. This seems to influence more involvement in low-key political activities (signing petitions, donating money...) than in active work towards positive social change (Ellis, 2004).

In this sense, this paper analyse the electoral participation of undergraduates in relation to different factor in Nicaragua, El Salvador, Chile, and Spain. These countries present different developmental levels that held de first free elections following their respective dictatorships within a thirteen year span. In this paper we will make a literature review about the factors that influence electoral behaviour to compare it with our data analysis. In our final results we show that the best predictors of electoral participation of undergraduates are related to their nationality, economic status, interest in politics, gender or living away from home.

\section{Literature Review}

While there are many factors that can influence electoral behavior, literature has paid particular attention to issues relating to socioeconomic aspects (social class, economic situation...), underscoring, at least in the United States, a correlation between socioeconomic capacity (with what this entails: money, education, personal resources...) and political participation (Leighley, 1995); those individuals with greater socioeconomic resources can cope more easily with expenses associated with electoral participation: registration, collecting information, travel to the polls, and so on (Johnson, Stein and Wrinkle 2003).

Cognitions associated with politics (ideology, interests...) are among the major factors used when analyzing electoral performance. Together with this, other aspects appear to also influence electoral performance, such as the perception of efficacy and confidence in certain institutions, as well as membership in associations, organizations... This aspect, brought up by Almond and Verba (1963) in the sixties, became a major area of interest in the English-speaking world (Parry, Moyser, \& Day, 1992; Verba, Schlozman, \& Brady, 1995; Moyser \& Parry, 1997) as well as in Europe (Dekker, Koopmans, \& Van de Broek, 1997; Stolle \& Ronchon, 1999) and Central America (Seligson, 1999); a positive correlation is observed between membership in associations or organizations and political activity of its members. The formation of share capital arising from affiliation with organizations is listed as one of the most relevant mechanisms in explaining the political activity of individuals (Teorell, 2003; Bekkers, 2005).

Nicaragua, El Salvador, Chile and Spain, countries with very different developmental levels, held the first free elections following their respective dictatorships within a thirteen year span: in 1977 Spain; 1984, El Salvador; 1989, Chile; and in 1990, Nicaragua. Currently, the electoral processes in such states conform to democratic standards; though this does not prevent the occasional rise of allegations of electoral fraud (Vázquez, Panadero, \& Rincón 2005). These states present differences in their institutional organizations (presidencialist systems in Chile, Nicaragua, and El Salvador, parliamentary monarchy in Spain; unicameral systems in El Salvador and Nicaragua and bicameral in Chile and Spain), and in their electoral systems (compulsory voting and pre-registration in Chile, voting age at sixteen in Nicaragua, etc.), which may influence electoral participation. The official voter turnout rates vary between the highest Chilean rates $(86.6 \%$ in the 2001 presidential and parliamentary elections and $87 \%$ in the 2005 presidential election), and the lowest in El Salvador (67.4\% in the 2004 presidential election) or Spain $(68.7 \%$ in the 2000 parliamentary election and $75.6 \%$ in the 2004 general election). Voter turnout in Nicaragua stood at $76.4 \%$ and $75 \%$ in the 1996 and 2001 
presidential elections, respectively.

Next to these political factors, there are other characteristics that distinguish these countries significantly, some of which are summarised in Table 1.

\section{Method}

Participants were 709 psychology undergraduates from Nicaragua ("Universidad Nacional Autónoma de Nicaragua" in León and "Universidad Autónoma de Chinandega"), El Salvador ("Universidad Centroamericana José Simeón Cañas" and "Universidad Evangélica" of El Salvador), Chile ("Universidad de Concepción" and "Universidad Santo Tomás") and Spain (Universidad Complutense de Madrid). Because of age constraints that excluded students that were unable to vote in recent elections in their country, the final sample size consists of 656 students: 208 Nicaraguans, 193 Salvadorans, 139 Chileans, and 116 Spanish.

The participants are mostly women, with an average age of 22.41 years $(\mathrm{SD}=4.456)$, and the majority unmarried $(87.0 \%)$.

A self-administered questionnaire was used, which was designed in Spain and adapted to include all the different Spanish language variants utilized in America. Administration of the questionnaire, conducted in the classrooms, was collective. No time limit was established to answer the questionnaire. Data was collected during the year 2007.

From information gathered from the questionnaire, the following was used for this study:

- Sociodemographic data, including perception of the social class to which they belong;

- Professional goals, emigration, and degree of satisfaction with the economic situation of their families;

- Political attitudes, exercising the right to vote, and participation in organizations;

- Pride of origin (nationality) and degree of trust in institutions;

- Stressful life events, compiled using a modified version of the LTE-Q (List of Threatening Experiences Questionnaire; Brugha and Cragg, 1990).

The analyses were carried out using the Statistical Package for the Social Sciences (Version 12.0). Comparisons were made in different variables among those who exercised their right to vote and those who did not. Data was analyzed using the Chisquare test for comparison of nominal variables, while an inde pendent sample's Student's t-test was utilized for continuous variables.

Discriminant analyses were performed using the stepwise inclusion method according to the "Wilks' Lambda" criterion, in which the dependent variable was defined as "exercised the right to vote", with two values: 0 , for individuals who did not vote; and 1 , for those who did vote. Statistical analysis of the differences between individuals who exercised and those that did not exercise this right led to selection of independent variables, including those variables in which both groups differed in a statistically significant way.

Due to an unequal group sample size, a random subgroup ( $\mathrm{n}=$ 151) was selected for discriminant analysis among individuals who voted.

\section{Results}

$76.2 \%$ of the samples (483 students) had voted in their country's most recent elections, although levels of participation differed greatly among countries $\left(\chi^{2}=236,855 ; p<0.001\right)$ : Chilean students present turnout rates $(26.9 \%)$ significantly lower than the Spanish $(81.7 \%)$, Nicaraguan $(87 \%)$, and Salvadoran $(95 \%)$ students.

Table 2 shows several socio-demographic characteristics of individuals who voted and those who did not.

As shown in Table 2, although both groups consisted mostly of women, the percentage of women is significantly higher among those who voted ( $83 \%$ versus $71.5 \%)$. Also, the group formed by those who voted is characterized by having a higher average age (22.6 years versus 21.4 years) and a smaller percentage of singles $(86.4 \%$ versus $95.3 \%)$.

Table 3 contains several socioeconomic characteristics of those who exercised their right to vote and those who did not.

As shown in Table 3, those who voted have a higher percentage of dissatisfaction with their family economic situation, predominantly belong to "lower-middle" and "lower" social classes, have a higher percentage of combining studies with work activity, and feel a higher sense of national pride. There were no significant differences in exercising the right to vote in relation to such factors as contemplating the possibility of "practicing their profession as psychologists in the future", considering that "their career prospects would improve outside their country", or "have weighed the possibility of emigrating".

Table 1.

Characteristics of Chile, Spain, Nicaragua and El Salvador.

\begin{tabular}{|c|c|c|c|c|}
\hline & Chile & Spain & Nicaragua & El Salvador \\
\hline Extension in $\mathrm{km}^{2}$ & 748,800 & 504,800 & 120,254 & 20,720 \\
\hline Total population (millions) $^{*}$ & 17.1 & 45.3 & 5.8 & 6.2 \\
\hline Year of enactment of the Constitution & 1980 & 1978 & 1987 & 1983 \\
\hline Human Development Index (HDI) rank ${ }^{*}$ & 45 & 20 & 115 & 90 \\
\hline Life expectancy at birth (years) ${ }^{*}$ & 78.8 & 81.3 & 73.8 & 72 \\
\hline Adult literacy rate (\% aged 15 and above) ${ }^{*}$ & 98.6 & 97.6 & 78 & 84 \\
\hline GDP per capita (PPP US\$) ${ }^{*}$ & 13,561 & 29,669 & 2567 & 6498 \\
\hline Population below income poverty line (\%) ${ }^{*}$ & --- & --- & 45.8 & 30.7 \\
\hline
\end{tabular}

Note: ${ }^{*} U N D P, 2010$. 
Table 2.

Gender, age, and marital status in relation to electoral participation.

\begin{tabular}{lccc}
\hline & $\begin{array}{c}\text { Voted } \\
(\mathrm{n}=483)\end{array}$ & $\begin{array}{c}\text { Not voted } \\
(\mathrm{n}=151)\end{array}$ & $\chi^{2 / \mathrm{t}}$ \\
\hline Gender & & & $10.209^{* * *}$ \\
Male & $71.5 \%$ & $28.5 \%$ & \\
Female & $83.3 \%$ & $16.7 \%$ & \\
Mean age (SD) & 22.6 & 21.39 & $4.105^{* * *}$ \\
Marital status & $(4.574)$ & $(2.509)$ & \\
Single & & & $9.271^{*}$ \\
Married or living together as a couple & $11.7 \%$ & $4.7 \%$ & \\
Separated or divorced & $86.4 \%$ & $95.3 \%$ & \\
Widowed & $1.7 \%$ & --- & \\
\hline
\end{tabular}

Note: ${ }^{*} p \leq 0.05 ;{ }^{* * *} p \leq 0.001$.

Table 3.

Socioeconomic characteristics in relation to electoral participation.

\begin{tabular}{lccc}
\hline & $\begin{array}{c}\text { Voted } \\
(\mathrm{n}=483)\end{array}$ & $\begin{array}{c}\text { Not voted } \\
(\mathrm{n}=151)\end{array}$ & $\chi^{2}$ \\
\hline Social class perceived & & & $10.406^{*}$ \\
High & $0.6 \%$ & --- & \\
Middle-high & $12.0 \%$ & $14.7 \%$ & \\
Middle & $57.1 \%$ & $67.3 \%$ & \\
Middle-low & $25.1 \%$ & $16.0 \%$ & \\
Low & $5.3 \%$ & $2.0 \%$ & \\
Household economic situation & & & $12.705^{*}$ \\
Very satisfactory & & & \\
Satisfactory & $9.1 \%$ & $15.9 \%$ & \\
Neither satisfactory nor unsatisfactory & $35.7 \%$ & $28.5 \%$ & \\
Unsatisfactory & $19.9 \%$ & $13.2 \%$ & \\
Very unsatisfactory & $4.1 \%$ & $2.6 \%$ & \\
Combine studies with work activities & $45.0 \%$ & $20.3 \%$ & $29.018^{* * *}$ \\
Sense of national pride & & & $17.577^{* * *}$ \\
Very high & & $39.7 \%$ & \\
High & $52.5 \%$ & $34.7 \%$ & \\
Low & $32.9 \%$ & $42.0 \%$ & \\
Very low & $12.7 \%$ & $18.0 \%$ & \\
\hline & $1.9 \%$ & $5.3 \%$ & \\
\hline
\end{tabular}

Note: ${ }^{*} p \leq 0.05 ;{ }^{* * *} p \leq 0.001$.

Table 4 reflects the differences between those who exercised and not exercised their right to vote according to their position in the political spectrum and degree of interest in politics.

Both groups are very similar with respect to their position in the political spectrum; without statistically significant differences in this regard: the majority of students are politically inclined towards "center" or "center-left" politics.
Those who voted significantly showed a higher interest in politics, basically half of them acknowledged a "high" or "very high" interest, reducing the percentage of those who did not vote to a third.

There were no statistically significant differences among those who voted and those who did not in the level of confidence expressed in the "legal system" or "representative and senate chambers". However, there are significant differences in the level of confidence in the "police" and "public officials or bureaucrats"; higher, in both cases, among those who did not vote (Table 5).

Table 6 shows that those who belong to "churches or religious organizations", "educational or artistic groups", "political parties or groups", "favoring human rights organizations", and

Table 4.

Position in the political spectrum and interest in politics in relation to electoral participation.

\begin{tabular}{lccc}
\hline & $\begin{array}{c}\text { Voted } \\
(\mathrm{n}=483)\end{array}$ & $\begin{array}{c}\text { Not voted } \\
(\mathrm{n}=151)\end{array}$ & $\chi^{2}$ \\
\hline Where are you in the political spectrum? & & & 2.140 \\
Left & $22.6 \%$ & $20.5 \%$ & \\
Center-left & $25.4 \%$ & $22.7 \%$ & \\
Center & $34.0 \%$ & $40.2 \%$ & \\
Center-right & $8.8 \%$ & $6.8 \%$ & \\
Right & $9.2 \%$ & $9.8 \%$ & \\
Degree of interest in politics & & & $15.450^{* * *}$ \\
Very high & $8.8 \%$ & $6.7 \%$ & \\
High & $37.1 \%$ & $27.3 \%$ & \\
Low & $43.3 \%$ & $43.3 \%$ & \\
Very low & $10.8 \%$ & $22.7 \%$ & \\
\hline Note: ${ }^{* * *} p \leq 0.001$. & & &
\end{tabular}

\section{Table 5.}

Degree of trust in different institutions in relation to electoral participation.

\begin{tabular}{lccc}
\hline & $\begin{array}{c}\text { Voted } \\
(\mathrm{n}=483)\end{array}$ & $\begin{array}{c}\text { Not voted } \\
(\mathrm{n}=151)\end{array}$ & $\chi^{2}$ \\
\hline Degree of trust in the police & & \multicolumn{3}{c}{$14.387^{* *}$} \\
Very high & $0.4 \%$ & --- & \\
High & $17.5 \%$ & $26.0 \%$ & \\
Low & $48.4 \%$ & $55.3 \%$ & \\
Very low & $33.6 \%$ & $18.7 \%$ & \\
Degree of trust in public officials or & & & $20.846^{* * *}$ \\
bureaucrats & & & \\
Very high & --- & --- & \\
High & $5.2 \%$ & $7.3 \%$ & \\
Low & $47.7 \%$ & $66.7 \%$ & \\
Very low & $47.1 \%$ & $26.0 \%$ & \\
\hline
\end{tabular}

Note: ${ }^{* * *} p \leq 0.001$. 
Table 6.

Memberships in associations, groups or organizations in relation to electoral participation.

\begin{tabular}{|c|c|c|c|}
\hline & $\begin{array}{c}\text { Voted } \\
(n=483)\end{array}$ & $\begin{array}{l}\text { Not voted } \\
(\mathrm{n}=151)\end{array}$ & $\chi^{2}$ \\
\hline $\begin{array}{l}\text { Belonging to churches and religious } \\
\text { organizations }\end{array}$ & $50.0 \%$ & $37.7 \%$ & $6.927^{* *}$ \\
\hline $\begin{array}{l}\text { Belonging to educational or artistic } \\
\text { groups }\end{array}$ & $37.1 \%$ & $28.2 \%$ & $3.956^{*}$ \\
\hline Belonging to unions & $2.9 \%$ & $0.7 \%$ & 2.498 \\
\hline Belonging to political parties or groups & $9.4 \%$ & $3.3 \%$ & $5.735^{*}$ \\
\hline $\begin{array}{l}\text { Belonging to favouring human rights } \\
\text { organizations }\end{array}$ & $15.9 \%$ & $5.3 \%$ & $11.001^{* * *}$ \\
\hline Belonging to youth groups & $37.6 \%$ & $32.7 \%$ & 1.190 \\
\hline Belonging to student organizations & $17.6 \%$ & $13.4 \%$ & 1.437 \\
\hline $\begin{array}{l}\text { Belonging to non-governmental } \\
\text { organizations or volunteer groups }\end{array}$ & $30.4 \%$ & $19.5 \%$ & $6.794^{* *}$ \\
\hline
\end{tabular}

Note: ${ }^{*} p \leq 0.05 ;{ }^{* *} p \leq 0.01 ;{ }^{* * *} p \leq 0.001$.

"non-governmental organizations or aid volunteer groups" show higher electoral participation.

The analysis of stressful events experienced by those interviewed (Table 7) suggests that those who have endured greater economic problems tend to vote more. On their part, students who are away from home appeared to show lower electoral participation. There are no statistically significant differences between voters and non-voters with respect to the number of stressful life events experienced.

Discriminant analysis results indicate that the independent variables that best discriminate among voters and non-voters in recent elections (helping predict the group to which they belong) are: degree of interest in politics, pride of one's nationality, being Chilean, being Salvadoran, and living away from home. Inclusion of other variables does not contribute in a significant way to discrimination between the two groups, therefore, were not included in the discriminant function.

Table 8 reveals a statistically significant discriminant function, that correlates with group variables with a value of 0.672 , and whose Chi-square is statistically significant. The group centroids are 0.905 for the group consisting of those who did not exercise the right to vote and -0.905 for the group of those that did vote:

The standardized coefficients seen in Table 8 show the sign and magnitude assigned to each of the variables included in the discriminant function, which has a Wilks' Lambda value of $0.548(p<0.001)$. This function correctly classifies $80.0 \%$ of the cases, a figure that exceeds the maximum randomness criterion. $94.6 \%$ of the group that exercised the right to vote and $65.5 \%$ of the group that did not were correctly assigned to the right group. Both groups meet the accuracy classification criterion "a fourth greater than that obtained by random selection" (Hair et al., 1999). Thus, the combination that best explains electoral participation is: high or very high interest in politics, a strong sense of national pride, not being Chilean, being Salvadoran, and not living away from home.

A second discriminant analysis was performed excluding nationality, the results of which indicated that the independent variables that provide the best possible discrimination among
Table 7.

Significant economic problems, living away from home and number of stressful life events suffered in relation to electoral participation.

\begin{tabular}{lccc}
\hline & $\begin{array}{c}\text { Voted } \\
(\mathrm{n}=483)\end{array}$ & $\begin{array}{c}\text { Not vote } \\
(\mathrm{n}=151)\end{array}$ & $\chi^{2 / \mathrm{t}}$ \\
\hline Are you living away from home & $26.1 \%$ & $40.0 \%$ & $10.694^{* * *}$ \\
$\begin{array}{l}\text { Have you endured significant } \\
\text { economic problems }\end{array}$ & $54.9 \%$ & $39.7 \%$ & $10.558^{* * *}$ \\
$\begin{array}{l}\text { Average number of stressful life } \\
\text { events (SD) }\end{array}$ & $2.90(2.244)$ & $2.55(2.034)$ & 1.643 \\
\hline Note: ${ }^{* * *} p \leq 0.001$. & & & \\
\end{tabular}

Table 8.

Standardized canonical discriminant function coefficients.

\begin{tabular}{lc}
\hline & Function \\
\cline { 2 - 2 } & 1 \\
\hline High or very high degree of interest in politics & -0.241 \\
High or very high pride of origin (nationality) & -0.207 \\
Chilean nationality & 0.852 \\
Salvadoran nationality & -0.296 \\
Living away from home & 0.255 \\
\hline
\end{tabular}

those who voted in recent elections and those who did not are: degree of interest in politics, living away from home, combining studies and working activities, gender, and having endured significant economic problems.

The results listed in Table 9 reveal a statistically significant discriminant function, that correlates with group variables with a value of 0.391 , and whose Chi-square is statistically significant. The group centroids are -0.423 for the group formed by those who failed to exercise the right to vote and 0.423 for the group of those who did vote.

The standardized coefficients listed in Table 9 show the sign and magnitude assigned to each of the three variables included in the discriminant function, which has a Wilks' Lambda value of $0.847(p<0.001)$. This function correctly classifies $64.7 \%$ of the cases, a figure which exceeds the maximum randomness criterion. $66.4 \%$ of the group that voted and $63.0 \%$ of the group of those that did not were correctly assigned to the right group, showing that both groups meet the accuracy classification criterion (Hair, 1999), although in this case by a narrower margin than in the previous case. By excluding nationality, the combination that best explains exercising the right to vote is: high or very high interest in politics, combining studies and working activity, being a woman, having endured major economic problems, and not living away from home.

\section{Analysis and Discussion}

While there is a very high electoral participation among Salvadoran students -25 points higher than the official turnout rate of the country- and among Spanish and Nicaraguans-more than 10 points higher than the official turnout rates of their respective countries, electoral participation among Chilean students is remarkably low: 60 points below the official voter turnout in Chile. This data is particularly relevant considering that Chile is 
Table 9.

Standardized canonical discriminant function coefficients.

\begin{tabular}{cc}
\hline & Function \\
\cline { 2 - 2 } & 1 \\
\hline High or very high degree of interest in politics & 0.417 \\
Combine studies with work-related activities & 0.487 \\
Being a man & -0.527 \\
Having suffered significant economic problems & 0.353 \\
Living away from home & -0.524 \\
\hline
\end{tabular}

the country that officially presents the highest electoral participation of the four. The Chilean electoral registration process together with mandatory participation of the registered, compared with automated registration and voluntary participation in the other three countries, seems to discourage student voting behavior, despite them exhibiting a high interest in politics. Undoubtedly, as pointed out by different sources (Fuentes \& Villar, 2004), to encourage electoral participation of new voters - at least university students - it may be of importance to review the pre-registration and compulsory voting requirements at election time.

Female students have a higher rate of voter participation than their male counterparts, although this difference is not seen among Central American students analyzed separately (Vázquez, Panadero, \& Rincón, 2005, 2006). The Chilean and Spanish female students, however, are more inclined to vote than their male counterparts. Older students and those who live with a partner (perhaps because of their greater stability and age) tend to vote more. According to the observations of Hritzuk and Park (2000), the passage of time and personal stability among the Latino population in the United States appear to be associated with increased electoral participation.

Contrasting Leighley's observations (1995), which point out a direct link between socioeconomic status and political participation, this study reveals that the students most pleased with their economic situation, those belonging to the highest social classes and who don't combine their studies with working activities - perhaps the most satisfied with the status quo, show lower electoral participation. On the other hand, a worse economic situation seems to encourage voter behavior among psychology students. In fact, when analyzing the various stressful events experienced by the interviewees, one can observe that having endured "economic problems" is more common among those who voted. The perceived need to influence the political situation in order to improve one's personal situation could boost electoral participation.

While those who vote tend to be more interested in politics, electoral performance is not influenced by their position in the political spectrum, as voter turnout rates for those who consider themselves leftists are similar to those of rightists. Nevertheless, despite the absence of statistically significant differences, the students who declare themselves as "centrists" are less likely to vote, as they interpret that positioning themselves in the center of the political spectrum is not a political ideology, but a way of expressing non-identification with traditional parties and a loss of confidence in political forces. Thus far, this aspect does not seem to influence decisively on electoral participation, which is very high even among those considered to be located in "cen- ter" politics, since in fact, trust in the legal system or in the legislative chambers does not seem to correlate with electoral participation. However, those who express more confidence in the police and public officials have the lowest rates of voter turnout. Once more, satisfaction with the status quo may help explain loss of voting motivation.

Joining religious organizations, educational or artistic groups, political parties, favouring human rights organizations, or nongovernmental organizations, is associated with higher rates of voter turnout. This data confirms the correlation observed by different authors (Bekkers, 2005; Vázquez, Panadero, \& Rincón, 2005) among those belonging to associations, groups or organizations, and political activity of its members; reinforcing the theory raised by Teorell (2003) in which the mechanisms of shared capital formation arising from affiliation with organizations represent one of the most important mechanisms in the explanation of an individual's political activity.

Those studying in universities away from their home show lower electoral participation. The need to go to their place of residence to vote or, if that fails, being ready to vote in advance by mail, seems to reduce electoral participation among these youths. While economic problems and living away from home affect electoral partition, no differences are observed with respect to the number of stressful life events experienced, despite the negative effects of these on emotions (Vázquez, Panadero, \& Rincón, 2007).

\section{Conclusion}

Following the data analysis, we conclude that undergraduates from Salvador, Nicaragua, and Spain present a higher electoral participation than Chile. The best predictors of electoral participation of undergraduates are related to their nationality, economic status, interest in politics, gender or living away from home.

Along these lines, these discriminant analyses identify these factors as best indicators of electoral turnout: a high voter interest in politics, pride in one's nationality, and not living away from home. Once again, the latter situation emerges as a major factor in inhibiting the exercise of the right to vote. In this respect, facilitating voting by mail could favour electoral participation of new voters.

The observed low turnout of Chilean students, as opposed to the very high turnout of Salvadoran students, once again stands out in the discriminant analysis. A similar situation occurs when combining studies with some work-related activity or having endured significant economic problems, factors that are associated with an increased voter behaviour.

\section{REFERENCES}

Almond, G., \& Verba, S. (1963). The civic culture: Political attitudes and democracy in five nations. Princeton, NJ: Princeton University Press.

Bekkers, R. (2005). Participation in voluntary associations: Relations with resources, personality, and political values. Political Psychology, 26, 439-445. doi:10.1111/j.1467-9221.2005.00425.x

Brugha, T. S., \& Cragg, D. (1990). The list of threatening experiences: The reliability and validity of a brief life events questionnaire. Acta Psychiatrica Scandinavica, 82, 77-81.

doi:10.1111/j.1600-0447.1990.tb01360.x

Dekker, P., Koopmans, R., \& Van den Broek, A. (1997). Voluntary associations, social movements and individual political behaviour in Western Europe. In J. Van Deth (Ed.), Private groups and public life: 


\section{J. J. VÁZQUEZ ET AL}

Social participation, voluntary associations and political involvement in representative democracies (pp. 220-239). London: Routledge.

Ellis, S. J. (2004). Young people and political action: Who is taking responsibility for positive social change? Journal of Youth Studies, 7, 89-102. doi:10.1080/1367626042000209976

Fuentes, C., \& Villar, A. (2004). Registro automático. Presentation in the Chilean Senate. URL (last checked 15 May 2011). www.flacso.cl $/$ flacso $/$ main.php?page $=$ noticia\& code $=542$

Hair, J. F., Anderson, R. E., Tatham R. L., \& Black, W. C. (1999). Multivariate data analysis. Upper Saddle River, NJ: Prentice-Hall International.

Hritzuk, N., \& Park, D. K. (2000). The question of Latino participation: From an SES to a social structural explanation. Social Science Quarterly, 81, 151-166.

Johnson, M., Stein, R. M., \& Wrinkle, R. (2003). Language choice, residential stability, and voting among Latino Americans. Social Science Quarterly, 84, 412-424. doi:10.1111/1540-6237.8402012

Leighley, J. E. (1995). Attitudes, opportunities, and incentives: A field essay on political participation. Political Research Quarterly, 48, 181-209.

Moyser, G., \& Parry, G. (1997). Voluntary associations and democratic participation in Britain. In J. Van Deth (Ed.), Private groups and public life: Social participation, voluntary associations and political involvement in representative democracies (pp. 24-46). London: Routledge.

Parry, G., Moyser, G., \& Day, N. (1992). Political participation in Britain. Cambridge, MA: Cambridge University Press. doi: $10.1017 / \mathrm{CBO} 9780511558726$

Seligson, A. (1999). Civic association and democratic participation in Central America. A test of the Putnam Hypothesis. Comparative Political Studies, 32, 342-362. doi:10.1177/0010414099032003003

Stolle, D., \& Rochon, T. (1999). The myth of American exceptionalism: A three-nation comparison of associational membership and social capital. In J. Van Deth, M. Maraffi, K. Newton, \& P. Whiteley (Eds.), Social capital and European democracy (pp. 192-209). London: Routledge.

Teorell, J. (2003). Linking social capital to political participation: Voluntary associations and networks of recruitment in Sweden. Scandinavian Political Studies, 26, 49-66. doi:10.1111/1467-9477.00079

UNDP (United Nations Development Programme) (2010). Human Development Report 2010. The Real Wealth of Nations: Pathways to Human Development. New York: UNDP.

Vázquez, J. J., Panadero, S., \& Rincón, P. P. (2005). Actitudes hacia la política, asociacionismo y emigración entre estudiantes de psicología nicaragüenses. Revista Electrónica de Psicología Política, 8, 1-21.

Vázquez, J. J., Panadero, S., \& Rincón, P. P. (2006). Actitudes hacia la política, instituciones y emigración entre estudiantes salvadoreños. Revista Electrónica de Psicología Política, 11, 1-20.

Vázquez, J. J., Panadero, S., \& Rincón; P. P. (2007). Stressful life events in countries of differing economic development: Nicaragua, Chile, and Spain. Psychological Reports, 101, 193-201.

Verba, S., Schlozman, K. L., \& Brady, H. (1995). Voice and equality: civic voluntarism in American politics. Cambridge, MA: Harvard University Press. 